\title{
Article \\ The Influence of Fly Ash on the Mechanical Performance of Cementitious Materials Produced with Recycled Cement
}

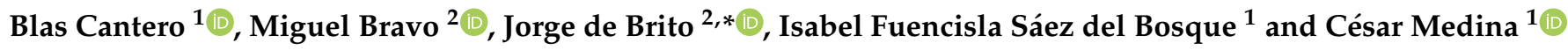 \\ 1 UEX-CSIC Partnering Unit, Institute for Sustainable Regional Development (INTERRA), \\ Department of Construction, School of Engineering, University of Extremadura, 1003 Cáceres, Spain; \\ bcanteroch@unex.es (B.C.); isaezdelu@unex.es (I.F.S.d.B.); cmedinam@unex.es (C.M.) \\ 2 CERIS, Department of Civil Engineering, Architecture and Georresources, Instituto Superior Técnico (IST), \\ Universidade de Lisboa, 1049-001 Lisbon, Portugal; miguelnbravo@gmail.com \\ * Correspondence: jb@civil.ist.utl.pt; Tel.: +351-218-418-118
}

check for

updates

Citation: Cantero, B.; Bravo, M.; de Brito, J.; del Bosque, I.F.S.; Medina, C. The Influence of Fly Ash on the Mechanical Performance of Cementitious Materials Produced with Recycled Cement. Appl. Sci. 2022, 12, 2257. https://doi.org/ 10.3390/app12042257

Academic Editor: Antonella D'Alessandro

Received: 17 January 2022

Accepted: 16 February 2022

Published: 21 February 2022

Publisher's Note: MDPI stays neutral with regard to jurisdictional claims in published maps and institutional affiliations.

Copyright: (c) 2022 by the authors. Licensee MDPI, Basel, Switzerland. This article is an open access article distributed under the terms and conditions of the Creative Commons Attribution (CC BY) license (https:// creativecommons.org/licenses/by/ $4.0 /)$.

\begin{abstract}
Concrete is the most widely used construction material in the world; as such, the best way to promote a more sustainable construction industry is to improve the environmental performance of this material. Since cement production is the main source of the high environmental impact of concrete, due to the high calcination temperature that clinker requires, replacing this binder with recycled cement would allow for the establishment of a new concrete design with a much lower ecological footprint. This research intends to analyse the mechanical performance of mortars with recycled cement and fly ash. Mixes with two replacement ratios of recycled cement (5\% and $10 \%)$ were studied separately or in combination with fly ash (10\% and $20 \%)$. An exhaustive experimental programme was designed to assess the variation in air content, density, compressive and flexural strengths, modulus of elasticity, and ultrasonic pulse velocity. The results suggest that the simultaneous use of recycled cement and fly ash improves the mechanical performance of mortars relative to those with recycled cement only or fly ash only.
\end{abstract}

Keywords: ternary binders; recycled cement; fly ash; waste concrete; eco-friendly cements; mechanical performance

\section{Introduction}

During the last decades, environmental concerns related to the manufacturing of ordinary Portland cement (OPC) and to the availability of new materials with the potential to reduce its consumption have driven the use of supplementary cementitious materials (SCMs) as an effective solution to optimize the production of clinker and reduce its large $\mathrm{CO}_{2}$ emissions [1].

Currently, a wide variety of SCMs is available from the recovery of industrial byproducts from biomass waste [2-4], ornamental industry sludge [5-7], calcined clays [8], etc. On the basis of the advances on the research on OPC substitution materials, an ambitious goal has been set to reduce the global clinker factor, on average, from 0.78 to 0.60 by 2050 [9]. This requires progress in the development of sustainable alternatives that can contribute to the reduction of the demand for natural resources in the cement industry. More recently, and due to the great problem caused by construction and demolition waste (CDW) [10], some researchers have tried to study the feasibility of using cement-based additions from concrete waste with partial replacement of clinker of cement, although these are still very limited. Recent studies indicate that the fine wastes $(<63 \mu \mathrm{m})$ from the crushing and grinding of demolished concrete show chemical compositions similar to those of hydrated Portland cement, with $\mathrm{SiO}_{2}$ and $\mathrm{CaO}$ as the main oxides, as well as other non-hydrated cement particles [11,12], and calcite $\left(\mathrm{CaCO}_{3}\right)$, which can be attributed to a portion of the carbonated cement paste [13]. These compounds can contribute favourably to the hydration of cement and/or have a filler effect when a given fineness is reached [14]. Studies carried 
out on cement pastes that incorporated ground concrete waste as a cement replacement also found a reduction in fluidity and a delay in the initial setting time compared to pastes made with conventional cement, due to (i) a lower fineness, (ii) a greater number of larger particles, and (iii) the dilution effect associated with the lower cement content compared to conventional cement [15]. Based on these results, it is recommended that the maximum percentage of incorporation of ground concrete waste is equal to, or less than, $15 \%$ by weight.

The search to achieve a more energy efficient cement has also led to the joint incorporation of SCMs, in variable quality and quantities, to increase the levels of replacement of OPC with SCM $[15,16]$. Some studies have shown that ternary binders, which combine clinker and two SCMs, could reduce the global warming potential associated with cement manufacturing by up to $60 \%$ [17]. In line with this, Ibáñez-Gosálvez et al. [18] studied the behaviour of ternary mortars incorporating blast furnace slag, fly ash, and limestone. These authors observed that the flexural and compressive strengths of ternary mortars at older ages ( $>250$ days) were slightly higher than those shown by binary mortars and very similar to those of conventional mortars. These findings were justified by the more refined porous structure at older ages ( $>250$ days) of the ternary cementitious matrices with at least one active SCM (slag and/or fly ash) compared to those of the binary or of the conventional mortars. Regarding the use of recycled concrete powder in co-replacement with other additions, Chen et al. [19] studied ternary mortars that incorporated different percentages $(10 \%, 20 \%, 30 \%$, and $40 \%)$ of recycled concrete powder (RCP) in combination with $15 \%$ of silica fume (SF) or $15 \%$ of fly ash (FA). These authors generally observed that mortars manufactured with up to $20 \%$ of RCP had up to $15 \%$ lower compressive strength than a conventional mortar at 28 days of curing. However, when $10 \%$ of RCP was combined with $15 \%$ of SF or with $15 \%$ of FA, the compressive and flexural strengths of these mortars were slightly higher than those of the conventional mortar, since RCP has some ability to improve the pozzolanic reactions of SF or FA.

In this context, a contribution to the knowledge of the existing scientific and technical gaps on the synergistic effects on the fresh- and hardened-states behaviour of mortars with ternary binder systems composed of cements mixed with recycled concrete powder (RC) and FA is still needed. For this purpose, the present study tries to deepen the understanding of the individual incorporation of RC (5-10\% by weight) and of FA (10-20\% by weight) in binary mortars and of the simultaneous incorporation of RC and FA (5-10\% by weight of RC and $10-20 \%$ by weight of FA) in ternary mortars. Hence, an extensive experimental campaign was carried out, which involved the characterization in the fresh state (workability, air content and density) and hardened state (flexural and compressive strengths, strength activity index, dynamic modulus of elasticity, and ultrasonic pulse velocity) of the produced mortars. In addition, the energy behaviour of all the mixes was evaluated in order to find the mortar with the lowest energy consumed per MPa of strength. These results may provide useful experience for the joint use of RC and FA in the design of new, more eco-efficient cement-based materials for application in the construction industry.

\section{Materials and Methods}

\subsection{Materials}

Fine $(0-2 \mathrm{~mm})$ and coarse $(2-4 \mathrm{~mm})$ siliceous sands were used in the production of the mortars. These sands have dry densities of $2637 \mathrm{~kg} / \mathrm{m}^{3}$ and $2617 \mathrm{~kg} / \mathrm{m}^{3}$, respectively, according to the EN 1097-6 standard [20]. Furthermore, the fine and coarse sands have, respectively, water absorptions of $0.4 \%$ and $0.5 \%$. In addition to these natural aggregates, the reference mortar (RM) was produced with ordinary Portland cement, OPC, type I $42.5 \mathrm{R}$ (CEM I $42.5 \mathrm{R})$.

The remaining mixes incorporate fly ash, FA, and recycled concrete powder (RC). Class F coal FA was provided by EDP—Gestão da Produção de Energia, S.A. at the Sines Power Plant, in Portugal. RC was obtained by crushing and grinding concrete specimens previously produced in the laboratory. Its composition was designed using the Faury 
method [21] with $300 \mathrm{~kg} / \mathrm{m}^{3}$ of CEM II/AL $42.5 \mathrm{R}$ cement, an effective water/cement ratio $\left(\mathrm{w} / \mathrm{c}_{\text {eff }}\right)$ of 0.55 , for an environmental exposure class $\mathrm{XC} 3$ and a target workability S3 according to the EN 206-1 standard [22]. Four types of natural aggregates were used in its manufacture: (i) coarse crushed limestone $(12 / 22 \mathrm{~mm})$ and (ii) medium-size crushed limestone $(6 / 12 \mathrm{~mm})$, as well as (iii) coarse $(2 / 4 \mathrm{~mm})$ and (iv) fine $(0 / 2 \mathrm{~mm})$ siliceous sand. The source concrete samples were manufactured and cast into $150 \mathrm{~mm}$ cubic and $150 \times 300 \mathrm{~mm}$ cylindrical specimens. After $24 \mathrm{~h}$, the specimens were demoulded and cured in the laboratory for 28 days in a saturated chamber ( $\mathrm{RH}>95 \%)$. After 28 days of curing, the original concrete had an average compressive strength of $39.8 \mathrm{MPa}$, measured in cubic specimens.

The chemical composition of the binders and aggregates used in the production of the mortars was analysed through X-ray fluorescence (XRF) using ZSX PRIMUS IV (Rigaku) equipment with a power of $4 \mathrm{~kW}$. The results obtained can be observed in Table 1 . Due to the siliceous nature of the natural aggregates, $\mathrm{SiO}_{2}$ is the oxide present in higher quantity in this material. In turn, it should be noted that the oxides present in higher quantities on the three binders studied (OPC, $\mathrm{RC}$, and $\mathrm{FA}$ ) are $\mathrm{SiO}_{2}, \mathrm{Al}_{2} \mathrm{O}_{3}$, and $\mathrm{CaO}$. However, in OPC, the high amount of $\mathrm{CaO}(67.1 \%)$ stands out, in the $\mathrm{RC}$, the high amounts of $\mathrm{SiO}_{2}(47.5 \%)$ and $\mathrm{CaO}(41.2 \%)$ are more evident, and in the FA, the high amounts of $\mathrm{SiO}_{2}(57.5 \%)$ and $\mathrm{Al}_{2} \mathrm{O}_{3}(24.4 \%)$ are the most obvious.

Table 1. XRF chemical composition of the raw materials.

\begin{tabular}{|c|c|c|c|c|c|}
\hline \multirow[b]{3}{*}{ Oxides } & \multicolumn{5}{|c|}{ Materials } \\
\hline & \multicolumn{3}{|c|}{ Binders } & \multicolumn{2}{|c|}{ Sands } \\
\hline & OPC (\%) & RC (\%) & FA (\%) & Fine $(\%)$ & Coarse $(\%)$ \\
\hline $\mathrm{Na}_{2} \mathrm{O}$ & 0.2 & 0.3 & 1.2 & 0.9 & 0.1 \\
\hline $\mathrm{MgO}$ & 1.9 & 0.5 & 1.8 & 0.1 & 0.0 \\
\hline $\mathrm{Al}_{2} \mathrm{O}_{3}$ & 5.3 & 3.9 & 24.4 & 7.0 & 3.9 \\
\hline $\mathrm{SiO}_{2}$ & 19.3 & 47.5 & 57.5 & 87.2 & 92.8 \\
\hline $\mathrm{P}_{2} \mathrm{O}_{5}$ & 0.0 & 0.0 & 0.4 & 0.0 & 0.0 \\
\hline $\mathrm{SO}_{3}$ & 3.1 & 0.4 & 0.8 & 0.0 & 0.0 \\
\hline $\mathrm{Cl}_{2} \mathrm{O}_{3}$ & 0.0 & 0.0 & 0.0 & 0.0 & 0.0 \\
\hline $\mathrm{K}_{2} \mathrm{O}$ & 0.5 & 1.2 & 2.7 & 4.0 & 2.4 \\
\hline $\mathrm{CaO}$ & 67.1 & 41.2 & 7.1 & 0.2 & 0.2 \\
\hline $\mathrm{TiO}_{2}$ & 0.0 & 0.0 & 1.0 & 0.1 & 0.1 \\
\hline $\mathrm{MnO}_{2}$ & 0.0 & 0.0 & 0.1 & 0.0 & 0.0 \\
\hline $\mathrm{Fe}_{2} \mathrm{O}_{3}$ & 2.7 & 1.5 & 2.6 & 0.4 & 0.5 \\
\hline $\mathrm{CuO}$ & 0.0 & 0.0 & 0.0 & 0.0 & 0.0 \\
\hline $\mathrm{ZnO}$ & 0.0 & 0.0 & 0.0 & 0.0 & 0.0 \\
\hline $\mathrm{SrO}$ & 0.0 & 0.0 & 0.1 & 0.0 & 0.0 \\
\hline $\mathrm{ZrO}_{2}$ & 0.0 & 0.0 & 0.0 & 0.0 & 0.0 \\
\hline $\mathrm{BaO}$ & 0.0 & 0.0 & 0.2 & 0.0 & 0.0 \\
\hline $\mathrm{Cr}_{2} \mathrm{O}_{3}$ & 0.0 & 0.0 & 0.0 & 0.0 & 0.0 \\
\hline
\end{tabular}

Note: OPC: ordinary Portland cement, RC: recycled cement, FA: fly ash.

Table 2 shows the physical properties of the different binders (OPC, RC, and FA), both in terms of their size and their density. The particle size distributions of the binders were obtained in a Mastersizer S. Analyser (Malvern Instruments) using ethanol as a dispersant.

D90 (90th percentile value for particle diameter) in RC was $147 \mu \mathrm{m}$, while in OPC and FA it was $46 \mu \mathrm{m}$ and $43.5 \mu \mathrm{m}$, respectively. This difference is associated with the natural aggregates present in the source concrete. The RC and FA used were less dense $\left(2.54 \mathrm{~g} / \mathrm{cm}^{3}\right.$ and $2.43 \mathrm{~g} / \mathrm{cm}^{3}$, respectively) than OPC $\left(3.11 \mathrm{~g} / \mathrm{cm}^{3}\right)$.

The morphology of the binders was obtained by scanning electron microscopy (SEM), using a JEOL JSM 7800 F. In Figures 1 and 2, SEM micrographs of FA and RC can be observed, respectively. FA has a mainly spherical structure. It can also be seen that most of the spheres have a diameter of approximately $10 \mu \mathrm{m}$, which is in agreement with the findings for the particle size distribution analysis performed (results presented in Table 2). 
Table 2. Physical properties of the binders.

\begin{tabular}{cccccc}
\hline \multirow{2}{*}{ Materials } & \multicolumn{3}{c}{ Sieve Size $(\boldsymbol{\mu m})$} & Per cent Passing $(\mathbf{\%})$ & \multirow{2}{*}{ Density $\left(\mathbf{g} / \mathbf{c m}^{\mathbf{3}}\right)^{\mathbf{1}}$} \\
\cline { 2 - 5 } & $\mathbf{1 0}$ & $\mathbf{5 0}$ & $\mathbf{9 0}$ & $<\mathbf{6 3} \boldsymbol{\mu \mathbf { m }}$ & 3.11 \\
\hline OPC & 1.9 & 13.8 & 46.0 & 97.9 & 2.54 \\
\hline RC & 1.6 & 21.2 & 147.0 & 67.8 & 2.43 \\
\hline FA & 0.7 & 7.6 & 43.5 & 96.9 & \\
\hline
\end{tabular}

Note: ${ }^{1}$ according to the UNE 80103 standard [23].

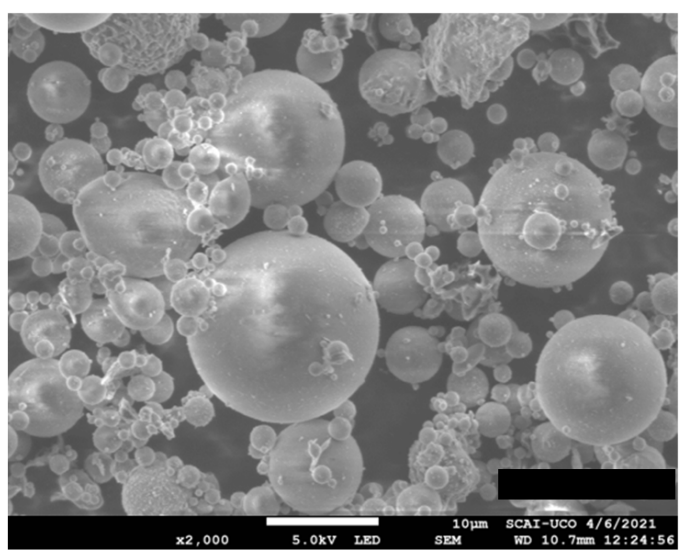

Figure 1. SEM image for FA.

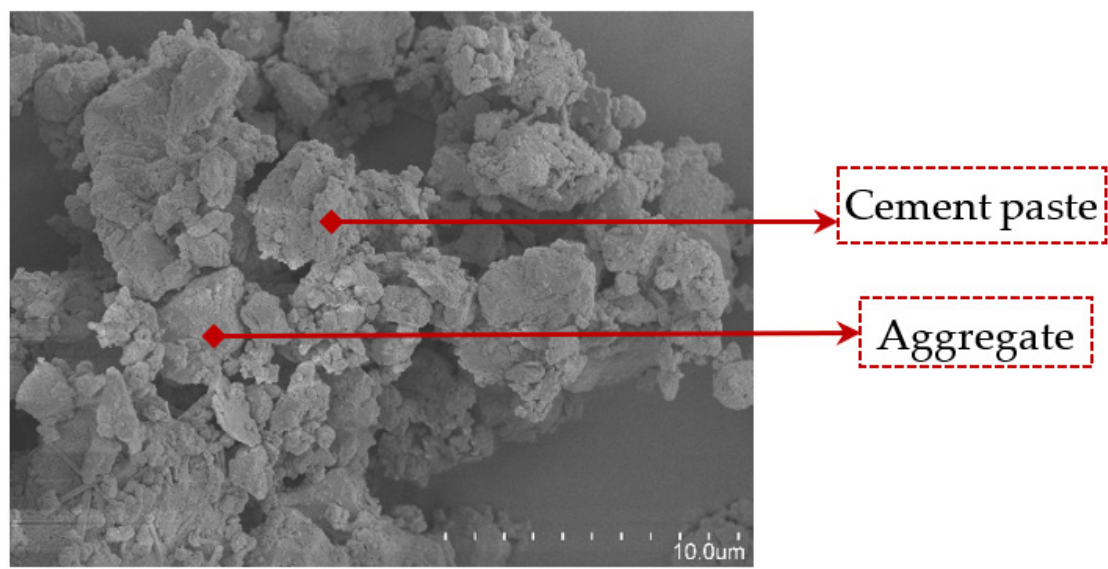

Figure 2. SEM image for RC.

Figure 2 allows for the evaluation of the differentiated structure of these wastes composed of cement paste and aggregates. Furthermore, compared with FA, RC particles show a much more irregular shape.

\subsection{Mix Design}

As mentioned above, the present experimental campaign intends to evaluate the individual incorporation of RC ( $5-10 \%$ by weight) and of FA (10-20\% by weight) in binary mortars, and the simultaneous incorporation, between $5 \%$ and $10 \%$ in weight, of RC and, between $10 \%$ and $20 \%$ in weight of, FA in mortars. The binder content and water/binder ratio were kept constant in all mortar formulations at $612 \mathrm{~kg} / \mathrm{m}^{3}$ and 0.50 , respectively. The composition of the reference mortar can be seen in Table 3 . 
Table 3. Composition of the reference mortar.

\begin{tabular}{|c|c|}
\hline Material & Proportion $\left(\mathrm{kg} / \mathrm{m}^{3}\right)$ \\
\hline $\mathrm{OPC}$ & 612 \\
\hline FA & 0 \\
\hline $\mathrm{RC}$ & 0 \\
\hline Total water & 306 \\
\hline Fine sand & 641 \\
\hline Coarse sand & 641 \\
\hline
\end{tabular}

\subsection{Mortar Properties Studied}

In this study, the characterization of the fresh- and hardened-state properties of the mortars was carried out. Consistency, density, and air content tests were carried out to characterize the properties of the fresh mortar, according to EN 1015-3 [24], EN 1015-6 [25], and EN 12350-7 [26], respectively. After moulding, performed with particular care to minimise pouring and consolidation times, the specimens were wrapped in plastic and stored for $24 \mathrm{~h}$. The demoulded specimens were stored in a humidity chamber at $20 \pm 2{ }^{\circ} \mathrm{C}$ and $95 \pm 5 \%$ humidity until tested. To determine the mechanical behaviour of the mortars, their flexural and compressive strengths and dynamic modulus of elasticity were determined. The compressive and flexural strengths of the mortars were tested in accordance with EN 1015-11 [27] on $160 \times 40 \times 40 \mathrm{~mm}$ prismatic samples. All the mixes were tested at 7, 91, and 365 days. In accordance with ASTM E1876-15 [28], the dynamic modulus of elasticity test was performed at 91 and 365 days. In addition to these tests, a non-destructive analysis of the ultrasonic pulse velocity was performed at 91 and 365 days, following EN 12504-4 [29]. Three specimens were produced per mix to analyse each of these properties.

Finally, the eco-efficiency of the material was studied through the method proposed by Hamidi et al. [30], which is based on the energy consumed in manufacturing the binders (binary and ternary) considering the manufacturing process (for example, heating of raw materials, burning of additions, and clinkerization) and final crushing of the material. The required energy $(E$, in $\mathrm{kW} \cdot \mathrm{h} / \mathrm{t})$ is a function of the composition of the binders and given by the energy necessary for their manufacture and grinding according to Equation (1):

$$
E(\mathrm{~kW} \cdot \mathrm{h} / \mathrm{t})=\sum_{i=0}^{n} C_{i} \cdot\left(E_{c i}^{\text {process }}+E_{i}^{\text {grinding }}\right)
$$

where $E$ is the energy consumed to produce $1 \mathrm{t}$ of binder, $C$ the proportion of the type of binder, OPC $(1,0.95,0.90,0.85,0.80,0.70), \mathrm{RC}(0,0.5,0.10)$, or FA $(0,0.10,0.20)$ in each mix, and $E_{c i}^{\text {process }}$ and $E_{c i}^{\text {grinding }}$ are the energies $(\mathrm{kW} \cdot \mathrm{h} / \mathrm{t})$ associated with production and grinding, respectively, to obtain each type of binder.

With the results of Equation (1), the energy performance of each type of mortar can be calculated according to Equation (2):

$$
E_{\text {performance }}(\mathrm{kW} \cdot \mathrm{h} / \mathrm{t} \cdot \mathrm{MPa})=\frac{E}{f_{c m}}
$$

where $E$ is the energy consumed to produce $1 \mathrm{t}$ of binder and $f_{c m}$ the compressive strength of the mortar.

\section{Results and Discussion}

\subsection{Fresh-State Properties of the Mortars}

\subsubsection{Consistency}

Table 4 shows the consistency values obtained for the studied mortars. It shows two different behaviours depending on the type of waste analysed. On the one hand, the partial incorporation of $5 \%$ and $10 \%$, by weight, of RC causes a slight decrease in workability of $1.1 \%$ and $4.1 \%$, respectively, compared to the conventional mortar. This effect is mainly 
due to (i) a higher water absorption of the mortar present in its composition and (ii) a higher percentage of particles smaller than $10 \mu \mathrm{m}$ that absorb more water [31-33]. On the other hand, the partial incorporation of $10 \%$ and $20 \%$, by weight, of FA causes, respectively, an increase in workability of $7.7 \%$ and $17.0 \%$ with respect to the conventional mix. This effect is due to the more spherical shape of FA particles compared to those of OPC, which act as lubricants [34]. Regarding the simultaneous incorporation of RC and FA (mixes $\mathrm{M}-5 / 10$ and $\mathrm{M}-10 / 20)$, an increase in workability between $4.8 \%$ and $11.1 \%$, respectively, is obtained compared to the conventional mix. In addition, an increase between $6.0 \%$ and $15.8 \%$, respectively, is observed with respect to the binary mortars with only RC (M-5/0 and $\mathrm{M}-10 / 0)$. These findings reveal that the simultaneous incorporation of RC and FA can be an effective solution to mitigate the loss of workability and reduce the higher water demand caused by the use of RC. This observation is in line with the conclusions obtained in previous studies on ternary mortars that incorporated up to $40 \%$ of recycled concrete powder together with $15 \%$ of SF or $15 \%$ of FA [19].

Table 4. Fresh-state properties of the studied mortars.

\begin{tabular}{|c|c|c|c|c|c|c|c|}
\hline Parameter & $\mathbf{R M}^{1}$ & M-5/0 & M-10/0 & M-0/10 & M-0/20 & M-5/10 & M-10/20 \\
\hline Consistency (mm) & 271 & 268 & 260 & 292 & 319 & 284 & 301 \\
\hline Air content (vol\%) & 1.6 & 1.9 & 2.2 & 1.0 & 0.8 & 1.1 & 0.7 \\
\hline Density $\left(\mathrm{kg} / \mathrm{m}^{3}\right)$ & 2249 & 2221 & 2213 & 2230 & 2203 & 2227 & 2214 \\
\hline Differential & & \multicolumn{2}{|c|}{$\Delta$ with RC (\%) ${ }^{2}$} & \multicolumn{2}{|c|}{$\Delta$ with FA (\%) ${ }^{3}$} & \multicolumn{2}{|c|}{$\Delta$ with RC $\times$ FA $(\%)^{4}$} \\
\hline Consistency (mm) & - & -1.1 & -4.1 & 7.7 & 17.7 & 4.8 & 11.1 \\
\hline Air content (vol\%) & - & 18.8 & 37.5 & -37.5 & -50.0 & -31.3 & -56.3 \\
\hline Density $\left(\mathrm{kg} / \mathrm{m}^{3}\right)$ & - & -1.2 & -1.6 & -0.8 & -2.0 & -1.0 & -1.4 \\
\hline
\end{tabular}

Notes: ${ }^{1}$ RM: reference mortar; ${ }^{2} \Delta$ with RC $(\%)$ compares RM to M- $5 / 0$ and to M-10/0; ${ }^{3} \Delta$ with FA (\%) compares $\mathrm{RM}$ to $\mathrm{M}-0 / 10$ and to $\mathrm{M}-0 / 20$, and ${ }^{4} \Delta$ with $\mathrm{RC} \times \mathrm{FA}(\%)$ : compares RM to $\mathrm{M}-5 / 10$ and to $\mathrm{M}-10 / 20$.

\subsubsection{Air Content and Density}

The results of air content and fresh-state density of the analysed mixes are shown in Table 4. The incorporation of $5 \%$ and $10 \%$ of RC (mixes M-5/0 and M-10/0) leads to an increase of $18.8 \%$ and $37.5 \%$ of air content, respectively, compared to the conventional mix, due to a greater porosity of the adhered mortar and to a more irregular shape of the RC particles compared to the OPC particles (Figure 2). The incorporation of $10 \%$ and $20 \%$ of FA (mixes M-0/10 and M-0/10) leads to a decrease between $37.5 \%$ and $50.0 \%$, respectively, of air content with respect to the conventional mix, due to a more spherical shape and smoother surface of FA particles compared to OPC particles. Likewise, the simultaneous incorporation of RC and FA (mixes M-5/10 and M-10/20) produces a decrease in air content of $31.3 \%$ and $56.6 \%$, respectively, compared to the conventional mortar. This behaviour may be due to a possible filling effect of FA particles in the RC. Figure 3a shows the decreasing linear variation $\left(R^{2} \geq 0.83\right)$ between air content and consistency, highlighting the high linear correlation between these properties.

The incorporation of $\mathrm{RC}, \mathrm{FA}$, and the joint incorporation of $\mathrm{RC}$ and FA leads to slight (linear) decreases $\left(R^{2} \geq 0.92\right)$ of density, regardless of the type of waste considered (Figure $3 b$ ), due to the lower density of these additions with respect to the OPC (Table 2). Likewise, these decreases do not exceed $2 \%$ and all the values of density were within the normal range (2200-2250 kg/m ${ }^{3}$ ) for FA and for RC that replace cement $[35,36]$.

Finally, the simultaneous incorporation of RC and FA leads to a higher fresh-state density of mortars with respect to their binary counterparts (RC or FA). This effect may be mainly due to the filling effect of the FA particles in the voids of the RC particles, resulting in denser cementitious matrices. These observations are in line with the findings of Vance et al. [37] for ternary mortars made with limestone powder and FA. 


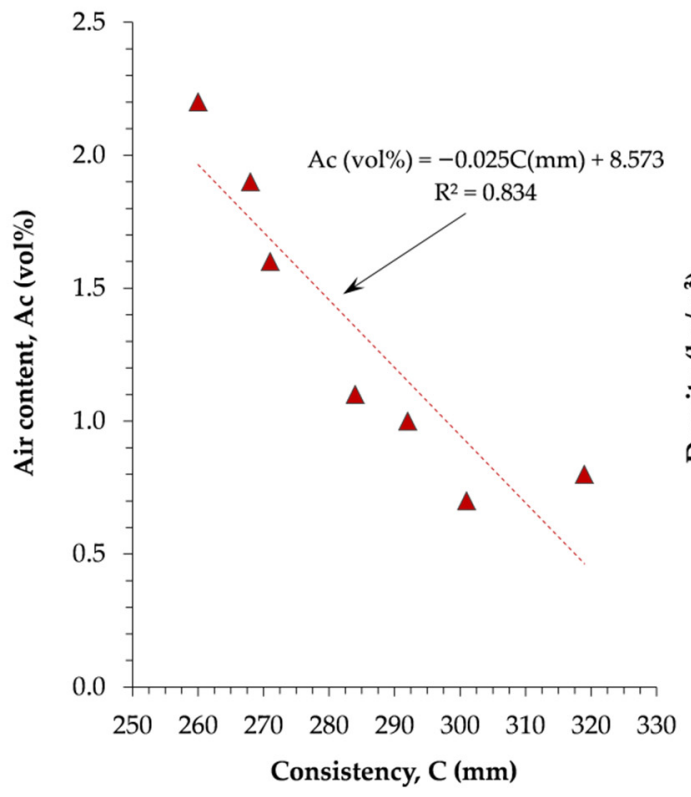

(a)

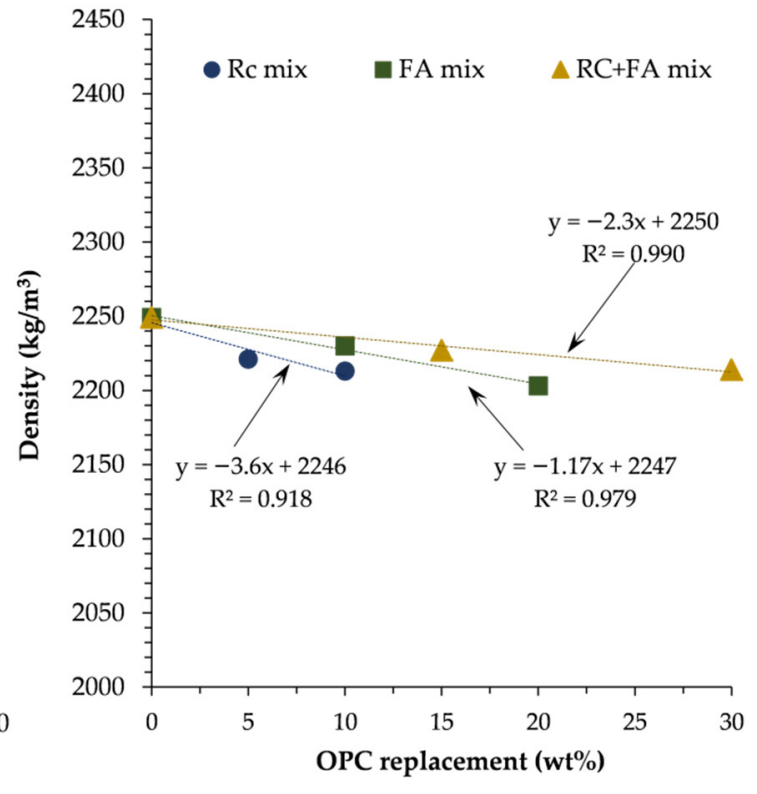

(b)

Figure 3. (a) Air content as a function of consistency (b) and variation in density with OPC replacement in the mixes.

\subsection{Hardened-State Properties of Mortars \\ 3.2.1. Compressive Strength}

The compressive strength results between 7 days and 365 days of curing are shown in Figure 4a. For ages up to 91 days, the binary mortars that incorporate between 5\% and $10 \%$ of RC show a compressive strength that is $11.5 \%$ and $23.9 \%$ (Table 5) lower than that of the conventional mortar, respectively, due to the dilution effect and low reactivity of the mortar. RC [15] and the mortars that incorporate between $10 \%$ and $20 \%$ of FA also decrease their compressive strength between $9.2 \%$ and $21.7 \%$, respectively, with respect to the conventional mortar because the clinker dilution effect still prevailed over the pozzolanicity of FA [38]. Regarding the compressive strength of the ternary mortars (simultaneous incorporation of RC and FA), they experienced a reduction between $6.1 \%$ (mix M-5/10) and $31.6 \%$ (mix M10/20) of this property compared to that of the conventional mortar. According to these results, the simultaneous use of RC and FA compared to the binary mortars, which only contain RC or FA, improves the compressive strength of mortars. These findings can be explained by the fact that RC complements the reactivity of active SCMs, as in the case of FA [39]. These results have also been previously observed in past investigations on ternary mortars that incorporate limestone powder $(10-20 \%)$ and FA $(10-30 \%)$ [40] or recycled concrete powder $(10-40 \%)$ in combination with SF and FA $(15-30 \%)$ [19].

At 365 days of curing, the ternary mortars that incorporate 5\% RC and 10\% FA show similar compressive strengths $(<2.5 \%)$ to that of the conventional mortar, and the compressive strength of mortars with $10 \% \mathrm{RC}$ and $20 \%$ FA show decreases of less than $10 \%$. This result is directly related to the changes induced by the simultaneous combination of the two additions (RC and FA), specifically in the refinement of the pore structure [19].

Finally, Table 6 shows that the individual and/or simultaneous incorporation of RC and FA as additions to the cement did not alter the logarithmic relationship between curing age and compressive strength. As seen there, the correlation coefficients $\left(R^{2}\right)$ were higher than 0.92 and similar to the $\mathrm{R}^{2}>0.94$ found for mortars that incorporated other additions, such as ash from biomass-fuelled power plants [4] or ornamental granite industry sludge [6], that replaced cement. 


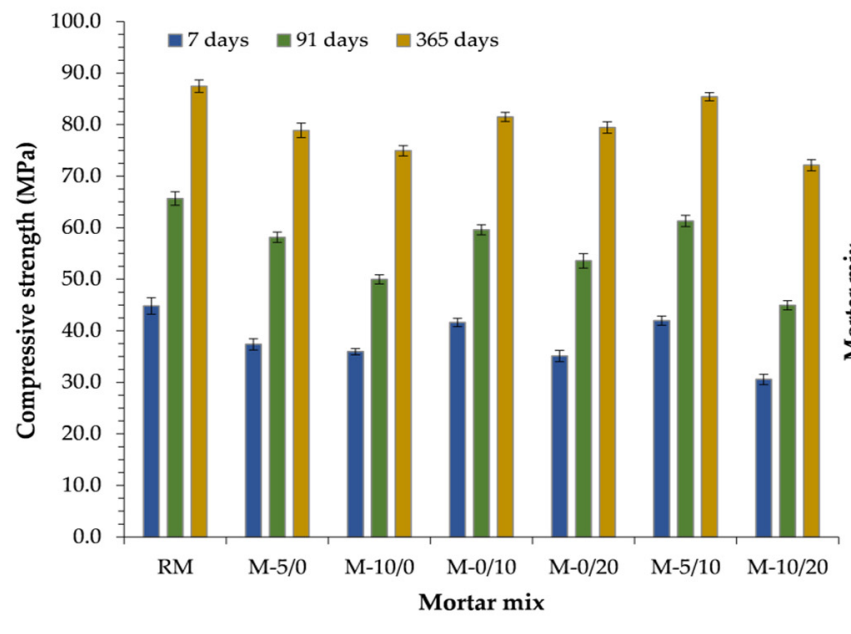

(a)

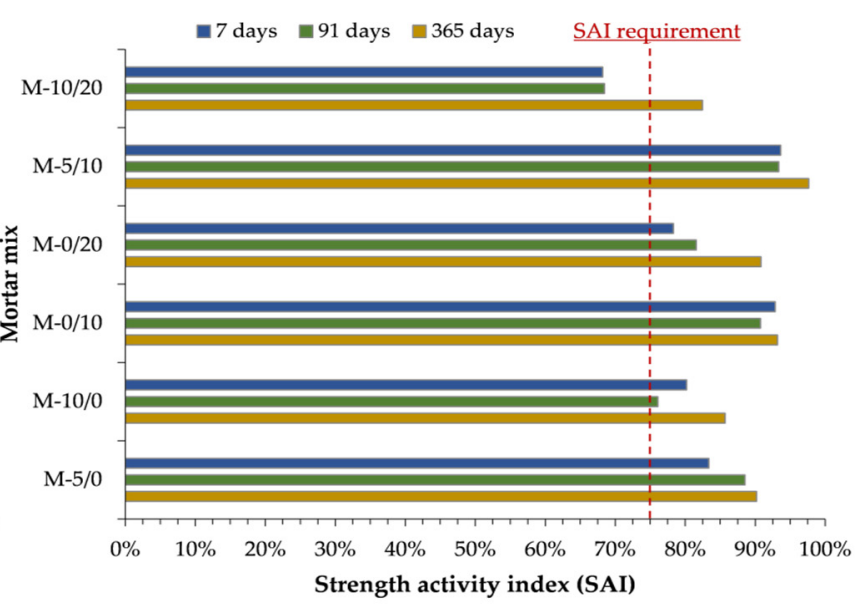

(b)

Figure 4. Results of (a) compressive strength and (b) strength activity index between 7 and 365 days of curing.

Table 5. Mechanical properties and quantification of the synergistic effects of the mortars.

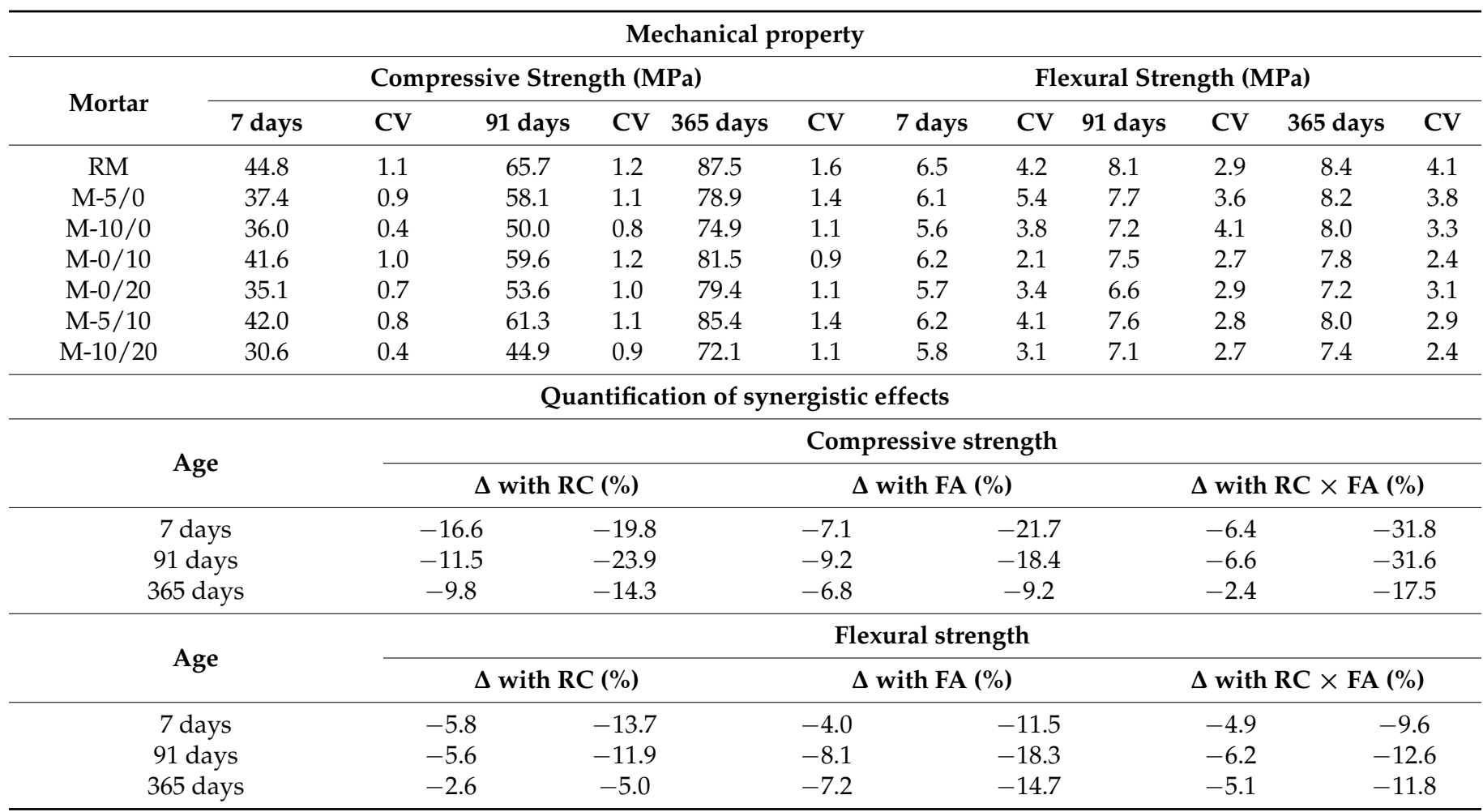

Note: CV: coefficient of variation in percent (\%). 
Table 6. Correlation between the mechanical properties and the curing age.

\begin{tabular}{ccccccc}
\hline \multicolumn{7}{c}{ Mechanical Property } \\
\hline \multirow{2}{*}{ Mortar } & \multicolumn{7}{c}{ Compressive Strength } & \multicolumn{3}{c}{ Flexural Strength } \\
\cline { 2 - 7 } & A & B & $\mathbf{R}^{\mathbf{2}}$ & A & B & $\mathbf{R}^{\mathbf{2}}$ \\
\hline RM & 10.43 & 22.92 & 0.967 & 0.51 & 5.58 & 0.949 \\
M-5/0 & 10.19 & 16.12 & 0.971 & 0.54 & 5.11 & 0.984 \\
M-10/0 & 9.31 & 15.27 & 0.925 & 0.61 & 4.41 & 0.999 \\
M-0/10 & 9.70 & 20.98 & 0.950 & 0.41 & 5.46 & 0.973 \\
M-0/20 & 10.71 & 11.90 & 0.931 & 0.36 & 5.02 & 0.998 \\
M-5/10 & 1055 & 19.42 & 0.946 & 0.40 & 5.12 & 0.971 \\
M-10/20 & 9.9 & 8.43 & 0.985 & 0.47 & 5.30 & 0.968 \\
\hline
\end{tabular}

Note: $y=\mathrm{A} \ln x+\mathrm{B}$; where $y$ is the mechanical property (compressive or flexural strength) value (MPa), A and B are constants, and $x$ is mortar age.

\subsubsection{Strength Activity Index}

The strength activity indices (SAI) of the mortars, between 7 days and 365 days of curing, are shown in Figure 4b. Although the replacement of OPC with RC or FA in binary mortars, and with RC and FA in ternary mortars, generally leads to a decrease in compressive strength after 7 days of curing in relation to the conventional mortar, all the mortars studied showed SAI values higher than $75 \%$. The latter value is required by the ASTM C618-19 [41] standard for cements containing up to 20\% FA or natural pozzolans after 7 days of curing; the exception was the mix that contained $10 \%$ of RC and $20 \%$ of FA. In this way, the SAI after 7 days of curing $\left(\mathrm{SAI}_{7 \text { days }}\right)$ (i) of the binary mortars produced with RC (5-10\%) was between $80 \%$ and $83 \%$, (ii) of the binary mortars produced with FA $(10-20 \%)$ was between $78 \%$ and $93 \%$, and (iii) of the ternary mortars, with the simultaneous incorporation of RC and FA, was between $68 \%(\mathrm{M}-5 / 10)$ and $94 \%(\mathrm{M}-10 / 20)$. These results are in agreement with those of Horsakulthai [42], who found values of $\mathrm{SAI}_{7 \text { days }}$ greater than, or equal to, $89 \%$ in mortars containing up to $20 \%$ of recycled concrete powder, as well as with the results of Jiang et al. [43] who determined that the $\mathrm{SAI}_{7 \text { days }}$ of ternary mortars that simultaneously incorporate limestone powder $(10 \%)$ and FA $(20 \%)$ was also higher than $85 \%$. At 365 days of curing, the highest value of SAI can be observed for the ternary mix with the simultaneous incorporation of $5 \%$ of RC and of $10 \%$ of FA, reaching a value of $\mathrm{SAI}_{365 \text { days }}=98 \%$. These results again reveal the positive synergies of jointly using $\mathrm{RC}$ and FA, compared to binary mortars that only incorporate RC or FA, in the improvements of the mechanical properties of mortars.

\subsubsection{Flexural Strength}

Figure 5 a shows the flexural strengths of the mortars between 7 days and 365 days of curing. These results show a similar behaviour pattern with those of compressive strength (Figure 4). Analysing the flexural strength values at 365 days of curing, the binary mortars with RC (5-10\%) show a slight decrease, between $2.6 \%$ and $5.0 \%$, compared to the conventional mortar, and the mortars with FA (10-20\%) show a decrease between $7.2 \%$ and $14.7 \%$. Regarding the ternary mortars with RC and FA, these also show slight decreases, between $5.1 \%(\mathrm{M}-5 / 10)$ and $11.8 \%(\mathrm{M}-10 / 20)$, with respect to the conventional mortar; these reductions of strengths being lower than those shown by the binary mortars with RA and FA. These results also indicate that all mixes produced, regardless of the type of addition, show decreases in this property lower than the percentage of replacement, attesting to the long life of the pozzolanic reactions that compensate for the loss of strength induced by the replacement of the clinker. Likewise, the relationship between flexural strength and curing age underwent an evolution according to a logarithmic-type regression with correlation coefficients $R^{2}>0.94$, similar to the pattern shown by the compressive strength with curing age (Table 6). 


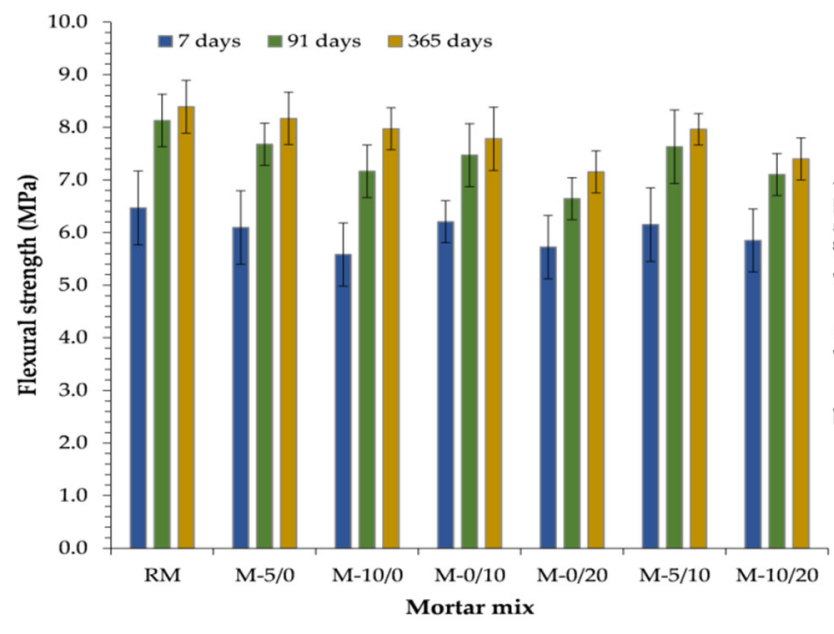

(a)

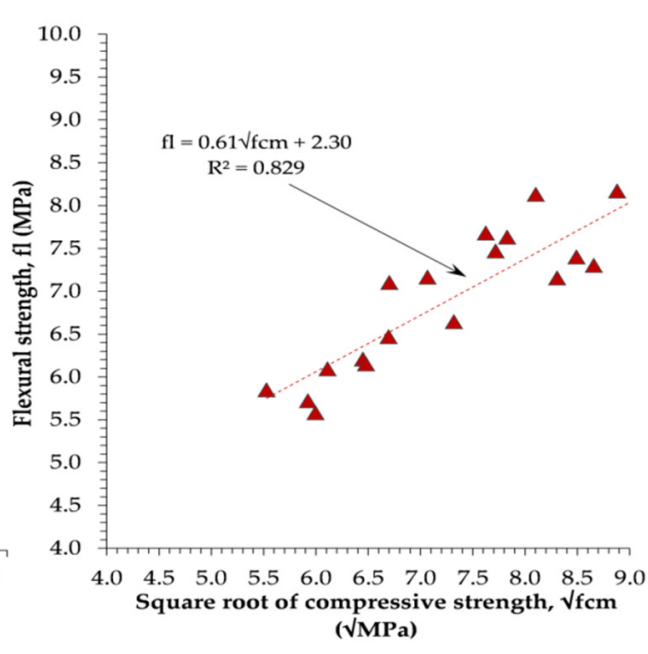

(b)

Figure 5. Results of flexural strength between 7 and 365 days of curing $(\mathbf{a}, \mathbf{b})$ and flexural strength as function of the square root of the compressive strength (at the same age).

Finally, it is common to express the flexural strength as a function of the compressive strength. Figure $5 b$ presents the linear relationship $\left(R^{2}>0.82\right)$ between the flexural strength and the square root of the compressive strength, highlighting that the incorporation of RC or FA individually, as well as of RC and FA simultaneously, does not affect this relationship that also exists for conventional mortars [44].

\subsubsection{Dynamic Modulus of Elasticity}

The results of the dynamic modulus of elasticity $\left(\mathrm{E}_{\mathrm{c}, \mathrm{dyn}}\right)$ at 91 days and 365 days of curing are shown in Table 7. $\mathrm{E}_{\mathrm{c}, \text { dyn }}$ values at 91 days of curing are between 35.2-38.0 GPa. Binary mortars that incorporate between $5 \%$ and $10 \%$ of RC show a decrease in this property between $4.7 \%$ and $4.9 \%$ compared to conventional mortar due to the dilution effect of RC [15]. The incorporation between $10 \%$ and $20 \%$ of FA also leads to a slight decrease in this property, between $3.7 \%$ and $7.4 \%$, respectively, compared to the conventional mortar, because the clinker dilution effect still prevailed over the FA pozzolanicity [43]. Regarding the influence of simultaneously incorporating $R C$ and $F A$, the reduction of $E_{c, \text { dyn }}$ was between $3.1 \%$ and $11.3 \%$ with respect to the conventional mortar.

As for 365 days, the $E_{c, d y n}$ values are higher than those shown at 91 days, as expected, due to a higher degree of hydration of the cementitious matrices, being between 37.5-38.3 GPa. Regarding the average variation of this property with curing age, ternary mortars (with RC and FA) experienced the greatest increase ( 7.7\%), and the binary mortars with RC $(\sim 4.8 \%)$ and FA $(\sim 5.7 \%)$ also showed increases higher than that observed for the conventional mortar $(\sim 0.9 \%)$. This fact is related to the increased reactivity of FA in the presence of RC, as was observed in the results of compressive strength, and by the new hydration reactions that occur at longer ages in the presence of RC [45] and FA [46].

Finally, Figure 6 shows the linear relationship between the dynamic modulus of elasticity and the square root of the compressive strength of the investigated mortars. The $\mathrm{R}^{2}$ coefficients are higher than 0.83 in both cases. These findings have also been confirmed for conventional mortars [44]. 
Table 7. Non-destructive mechanical and physical properties and the quantification of the synergistic effects of the mortars.

\begin{tabular}{|c|c|c|c|c|c|c|c|c|}
\hline \multicolumn{9}{|c|}{ Physical Property } \\
\hline \multirow{2}{*}{ Mortar } & \multicolumn{4}{|c|}{ Dynamic Modulus of Elasticity (GPa) } & \multicolumn{4}{|c|}{ Ultrasonic Pulse Velocity (km/s) } \\
\hline & 91 Days & $\mathrm{CV}^{1}$ & 365 Days & $\mathrm{CV}^{1}$ & 91 Days & $\mathrm{CV}^{1}$ & 365 Days & $\mathrm{CV}^{1}$ \\
\hline RM & 38.0 & 0.6 & 38.3 & 0.5 & 4.5 & 0.2 & 4.7 & 0.1 \\
\hline$M-5 / 0$ & 36.2 & 0.4 & 38.0 & 0.8 & 4.4 & 0.3 & 4.6 & 0.1 \\
\hline $\mathrm{M}-10 / 0$ & 36.1 & 0.1 & 37.8 & 0.7 & 4.4 & 0.8 & 4.6 & 0.4 \\
\hline $\mathrm{M}-0 / 10$ & 36.6 & 0.6 & 38.1 & 0.4 & 4.4 & 0.5 & 4.6 & 0.2 \\
\hline $\mathrm{M}-0 / 20$ & 35.2 & 0.8 & 37.7 & 0.3 & 4.3 & 0.5 & 4.5 & 0.2 \\
\hline M-5/10 & 36.8 & 1.0 & 38.3 & 0.8 & 4.4 & 0.4 & 4.7 & 0.2 \\
\hline $\mathrm{M}-10 / 20$ & 33.7 & 0.9 & 37.5 & 1.1 & 4.2 & 0.2 & 4.5 & 0.1 \\
\hline
\end{tabular}

Quantification of synergistic effects

\begin{tabular}{|c|c|c|c|c|c|c|}
\hline \multirow{4}{*}{$\begin{array}{c}\text { Age } \\
91 \text { days } \\
365 \text { days }\end{array}$} & \multicolumn{6}{|c|}{ Dynamic modulus of elasticity } \\
\hline & \multicolumn{2}{|c|}{$\Delta$ with RC (\%) } & \multicolumn{2}{|c|}{$\Delta$ with FA (\%) } & \multicolumn{2}{|c|}{$\Delta$ with RC $\times$ FA $(\%)$} \\
\hline & -4.7 & -4.9 & -3.7 & -7.4 & -3.1 & -11.3 \\
\hline & -0.8 & -1.4 & -0.6 & -1.6 & -0.1 & -2.1 \\
\hline \multirow{2}{*}{ Age } & \multicolumn{6}{|c|}{ Ultrasonic pulse velocity } \\
\hline & \multicolumn{2}{|c|}{$\Delta$ with RC (\%) } & \multicolumn{2}{|c|}{$\Delta$ with FA (\%) } & \multicolumn{2}{|c|}{$\Delta$ with $\mathrm{RC} \times \mathrm{FA}(\%)$} \\
\hline 91 days & -2.8 & -2.5 & -2.4 & -3.7 & -1.9 & -6.1 \\
\hline 365 days & -2.4 & -2.8 & -1.7 & -4.4 & -0.3 & -3.7 \\
\hline
\end{tabular}

Note: ${ }^{1} \mathrm{CV}$ : coefficient of variation in percent $(\%)$.

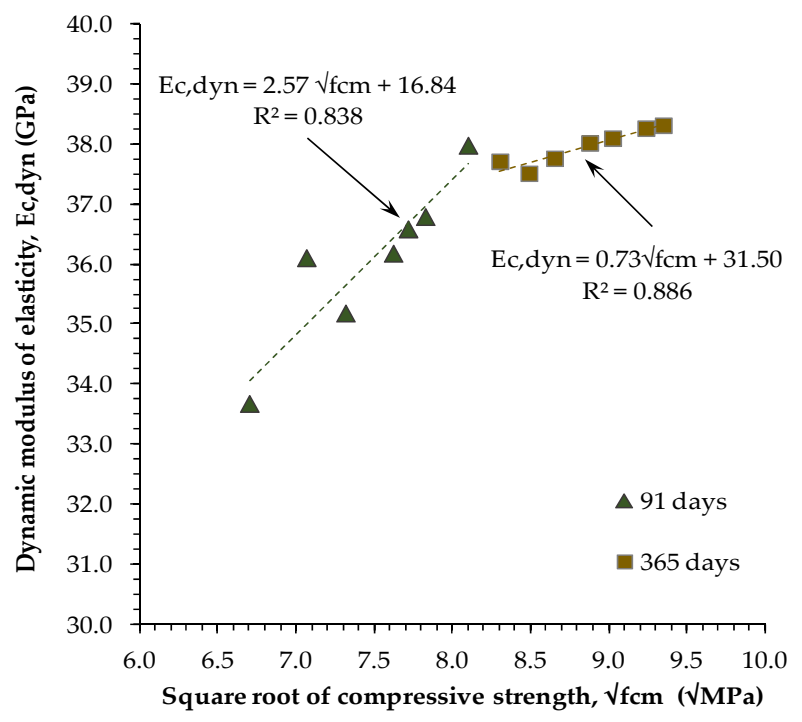

Figure 6. Dynamic modulus of elasticity at 91 and 365 days as a function of the square root of the compressive strength (at the same age).

\subsubsection{Ultrasonic Pulse Velocity}

Ultrasonic pulse velocity (UPV) results at 91 days and 365 days of curing of the mortars are shown in Table 7. In general, an increase in UPV is observed in all mortars with curing time (Figure 7a). This is due to the fact that, as the curing time increases, the hydration products that are generated fill the internal pores of the cementitious matrices [47]. The UPV at 91 days of curing is between 4.2 and $4.5 \mathrm{~km} / \mathrm{s}$; these values are within the range $(4.0-5.5 \mathrm{~km} / \mathrm{s})$ found for binary mortars containing other SCMs: fly ash, $<30 \%$ [40], silica fume, $<40 \%$ [48], limestone powder, $<20 \%$ [49], and ternary mortars containing limestone powder and $20 \%$ to $30 \%$ of fly ash $[18,50]$. Regarding the binary mortars, the incorporation of RC ( $5-10 \%)$ decreases the UPV between $2.5 \%$ and $2.8 \%$ compared to the conventional 
mortar, and the use of FA (10-20\%) leads to decreases between $2.4 \%$ and $3.7 \%$. The simultaneous incorporation of RC and FA results in a reduction of the UPV between $1.9 \%$ and $6.9 \%$ with respect to the conventional mortar.

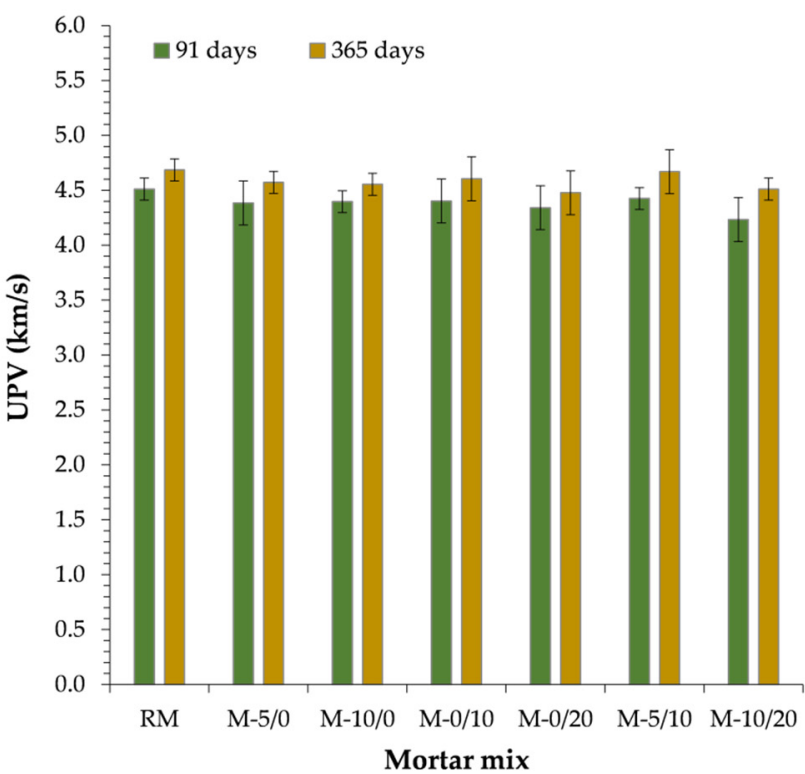

(a)

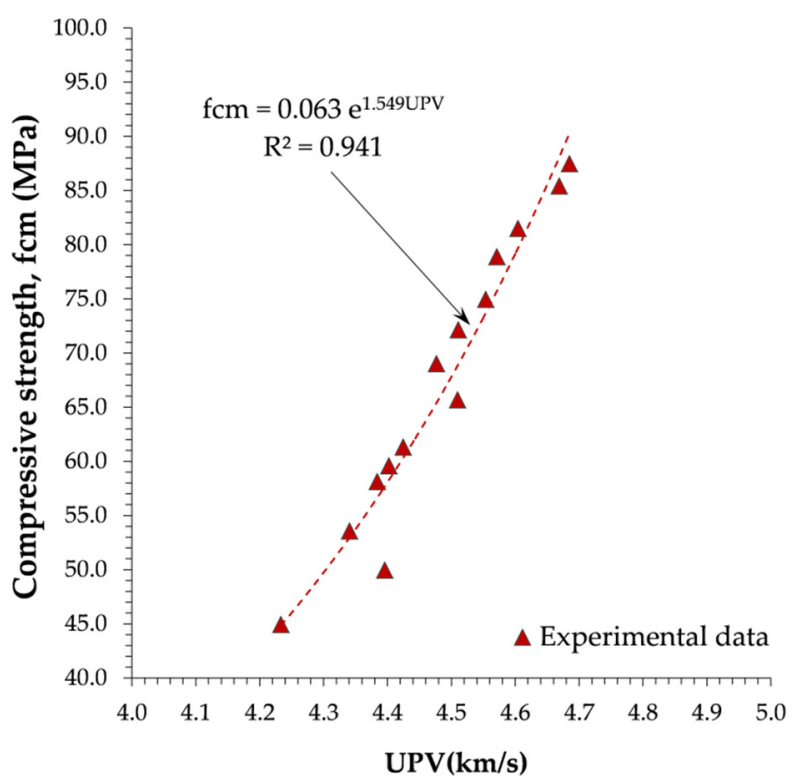

(b)

Figure 7. Results of ultrasonic pulse velocity at 91 and 365 days of curing $(\mathbf{a}, \mathbf{b})$ on the compressive strength, $f_{c m}$, of the mortar as a function of the ultrasonic pulse velocity, UPV.

Regarding the average increase of UPV between 91 days and 365 days of curing $\left(\mathrm{UPV}_{91 \mathrm{~d} \rightarrow 365 \mathrm{~d}}\right)$, the highest one is found for ternary mortars that jointly incorporate RC and FA $(\sim 6.0 \%)$, while for the binary mortars with RC or with FA, the increases were circa $3.9 \%$, which is similar to what was observed for the reference mortar $(\sim 3.8 \%)$. This behaviour is associated with the increased reactivity of FA in the presence of RC, causing the microstructure of ternary mortars (with FA and RC) to become denser compared to their binary counterparts that only incorporate RC or FA. These findings are consistent with the results for compressive strength (Section 3.2.2) and for the dynamic modulus of elasticity (Section 3.2.4), as shown above.

Some authors ([51-53]) consider UPV values greater than $4.5 \mathrm{~km} / \mathrm{s}$ to denote excellent quality mortars, and values between $3.6 \mathrm{~km} / \mathrm{s}$ and $4.5 \mathrm{~km} / \mathrm{s}$ correspond to good quality mortar. As the data in Table 7 show, all the mixes at 365 days of curing could be regarded as excellent quality mortars.

Compressive strength values in mortars and concrete can be calculated using UPV values with functions similar to Equation (3), as reported in previous work [48,54-56]:

$$
f_{c m}=\mathrm{A} \times e^{\mathrm{B} \cdot \mathrm{UPV}}
$$

where $f_{c m}$ is the compressive strength and $\mathrm{A}$ and $\mathrm{B}$ are empirical constants. As shown in Figure $7 \mathrm{~b}$, the compressive strength increased according to an exponential relationship, and the correlation coefficient, $\mathrm{R}^{2}$, was higher than 0.94 , which is in line with previous findings that reported for other SCMs such as FA, $R^{2}=0.97$ [55], SF, $R^{2}=0.96$ [48], or blast furnace slag, $R^{2}=0.94$ [43].

\subsubsection{Eco-Efficient Material}

The values used to estimate the energy consumed to manufacture a tonne of binder are shown in Table 8. For OPC (heating of raw materials, clinkerization, and crushing), these 
were extracted from the literature [30,57]. RC does not need calcination, but was crushed, and so the energy consumed in the grinding process of the concrete specimens manufactured in lab [31] was considered to be similar to the process necessary to grind concrete debris from CDW. For FA, only the energy consumed in its collection was considered [58].

Table 8. Values used to calculate the energy consumed.

\begin{tabular}{clcc}
\hline \multirow{2}{*}{ Process } & \multicolumn{3}{c}{ Energy Consumed [Refs.] } \\
\cline { 2 - 4 } & OPC & RC & FA \\
\hline Manufacture & $E_{O P C}^{\text {process }}=1039 \mathrm{~kW} \cdot \mathrm{h} / \mathrm{t}[45]$ & $E_{R C}^{\text {process }}=0 \mathrm{~kW} \cdot \mathrm{h} / \mathrm{t}^{1}$ & $E_{F A}^{\text {process }}=38 \mathrm{~kW} \cdot \mathrm{h} / \mathrm{t} \mathrm{[46]}$ \\
Grinding & $E_{O P C}^{\text {grinding }}=50 \mathrm{~kW} \cdot \mathrm{h} / \mathrm{t}[21]$ & $E_{R C}^{\text {grinding }}=140 \mathrm{~kW} \cdot \mathrm{h} / \mathrm{t}[22]$ & $E_{F A}^{\text {grinding }}=0 \mathrm{~kW} \cdot \mathrm{h} / \mathrm{t}^{2}$ \\
\hline
\end{tabular}

Notes: ${ }^{1} \mathrm{RC}$ requires no manufacture; ${ }^{2} \mathrm{FA}$ requires no grinding.

The results of energy consumption per MPa of strength are shown in Figure 8. After 7 days of curing (Figure 8a), the binary mortars that incorporate RC show the highest energy consumption per $\mathrm{MPa}$ of strength as a result of a lower initial strength and low reactivity of the SCMs [15]. Additionally, the binary mortars with FA and the ternary mortars with RC and FA show a slightly lower behaviour compared to the reference mortar with OPC because the clinker dilution effect still prevails over the pozzolanic reactions [38]. At 365 days of curing (Figure 8b), the energy consumption per MPa of strength decreases (with respect to the 7 days) due to the dilution effect and low reactivity of the $\mathrm{RC}$, showing a similar behaviour to the reference mortar $\left(\mathrm{E}_{\mathrm{con}} \sim 12.9 \mathrm{~kW} \cdot \mathrm{h} / \mathrm{t} \cdot \mathrm{MPa}\right)$. The lowest energy consumptions per MPa of strength were obtained for binary mortars with $\mathrm{FA}\left(\mathrm{E}_{\mathrm{con}} \sim 11.5 \mathrm{~kW} \cdot \mathrm{h} / \mathrm{t} \cdot \mathrm{MPa}\right)$ and ternary mortars with $\mathrm{RC}$ and $\mathrm{FA}\left(\mathrm{E}_{\mathrm{con}} \sim 11.2 \mathrm{~kW} \cdot \mathrm{h} / \mathrm{t} \cdot \mathrm{MPa}\right)$. These results coincide with previous findings obtained for mortars made with up to $20 \%$ ash from biomass-fuelled power plants compared to conventional mortar [4].

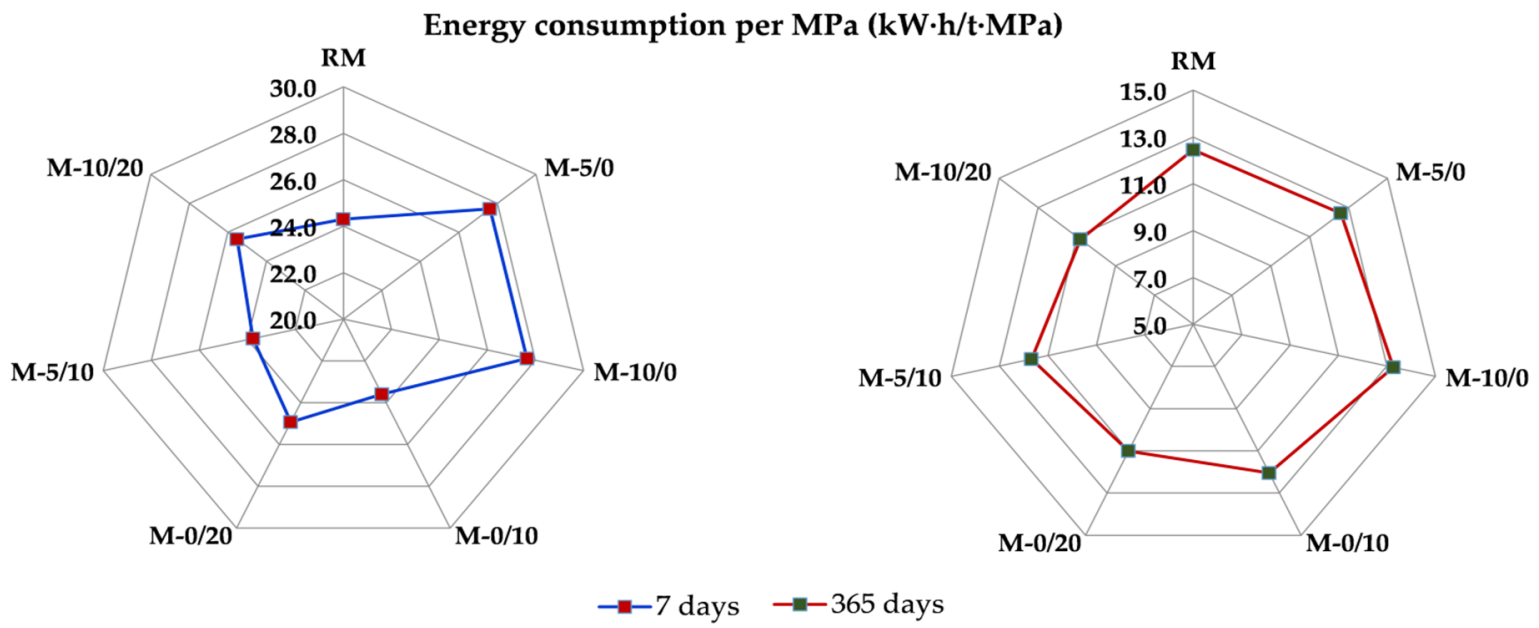

(a)

(b)

Figure 8. Energy performance at (a) 7 days and ((b) 365 days of mortars.

Figure 9 shows the synergistic effects of simultaneously incorporating RC and FA versus their individual incorporation. There, at 365 days of curing, the energy consumption per MPa of strength of the binary mortars with $5 \%$ of RC is similar $(\sim 1.2 \%)$ to that of the mortar with OPC. For the mortar with $20 \%$ FA, the energy consumption is reduced by up to $11.6 \%$ compared to the mortar with OPC. As for the ternary mortars, the reduction of consumed energy per MPa of strength can reach up to $13.2 \%$ with the simultaneous incorporation of $10 \%$ of RC and of $20 \%$ of FA, with respect to the mortar with OPC. 


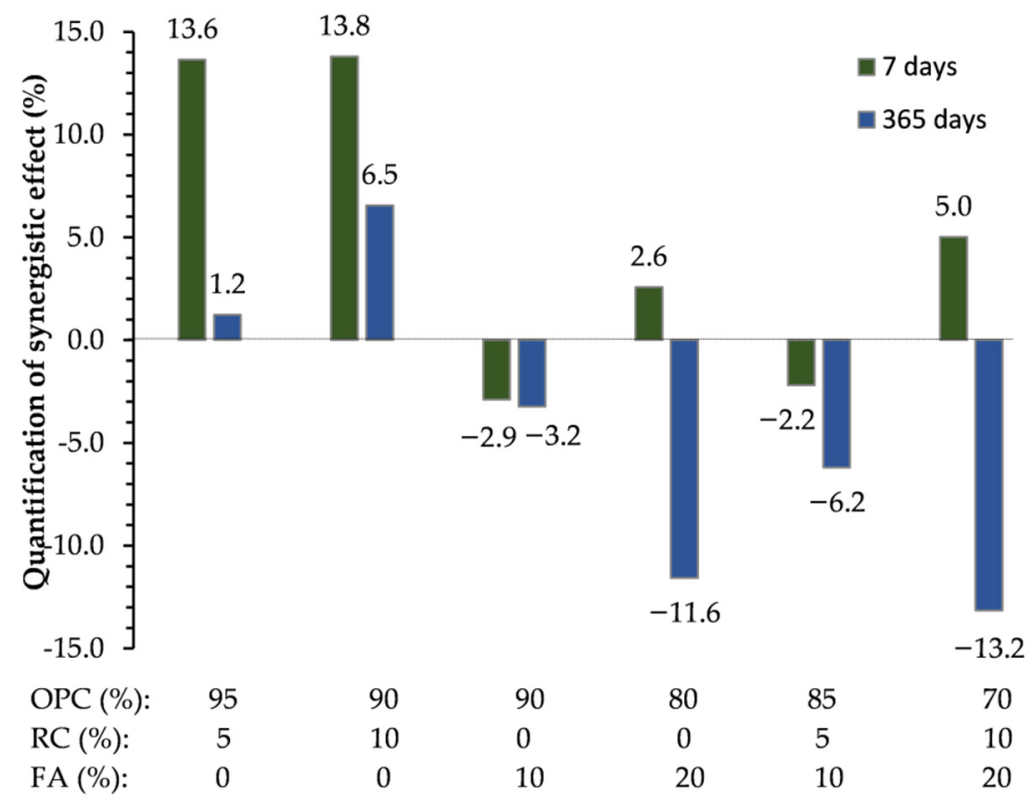

Figure 9. Quantification of synergistic effects on the 7-day and 365-day energy performance of the mortars.

Finally, it should be noted that the use of RC and FA as supplementary cementitious materials would also imply a reduction in $\mathrm{CO}_{2}$ emissions $\left(\Delta \mathrm{CO}_{2}\right.$ emissions) at rates close to the percentage of replacement, as observed by several authors, for $10 \%$ of RC [31] $\left(\Delta \mathrm{CO}_{2}\right.$ emissions $\left.=-7.5 \%\right)$ and for $20 \%$ of FA [58,59] $\left(\Delta \mathrm{CO}_{2}\right.$ emissions $\left.=-19.8 \% / 17.8 \%\right)$.

\section{Conclusions}

The conclusions that may be drawn from this study are set out below:

1. The incorporation of up to $10 \%$ of recycled concrete powder (RC) slightly decreases $(\sim 4 \%)$ workability, as compared to a conventional mortar, due to a greater demand for water because of the greater porosity of the adhered mortar present in this material. The simultaneous incorporation of $10 \%$ of RC and $20 \%$ of fly ash (FA) improves workability by up to $11.8 \%$ compared to mortars with only the incorporation of $10 \%$ of RC, being an effective solution to reduce the higher water demand caused by the use of RC;

2. In general, the fresh-state density of the binary mortars with RC or with FA is lower than that of the conventional mortar. However, the simultaneous incorporation of both additions ( $\mathrm{RC}$ and FA) leads to a higher density compared to their counterparts with only RC or only FA;

3. The compressive and flexural strengths of mortars are reduced (compared to conventional mortar) by the incorporation of RC (5-10\%). They are between $-9.8 \%(5 \%)$ and $-14.3 \%(10 \%)$ for compressive strength, and between $-2.6 \%(5 \%)$ and $-5.0 \%(10 \%)$ for flexural strength, at 365 days of curing. The addition of FA in the mortars with $\mathrm{RC}$ is beneficial, improving their mechanical performance. In this way, the ternary mortars that jointly incorporate $5 \%$ of RC and 10\% of FA show compressive and flexural strengths similar to those of the conventional mortar;

4. The dynamic modulus of elasticity was not significantly affected by the incorporation of RC, nor by the simultaneous incorporation of RC and FA, at 365 days of curing. All the mortars, regardless of the RC and/or FA content, showed a dynamic modulus of elasticity with values between $37.5 \mathrm{GPa}$ and $38.3 \mathrm{GPa}$;

5. The exponential relationship between compressive strength and ultrasonic pulse velocity (established for other cementitious materials) was not affected by the incorporation of RC and/or FA; 
6. The energy consumed per MPa of strength at 365 days of curing of the mortars with $5 \%$ of RC was similar to that of the conventional mortar. The simultaneous incorporation of both additions (RC and FA) reduces the energy consumed per MPa of strength (in comparison to the conventional mortar) by up to $13.2 \%$ when using $10 \%$ of RC and $20 \%$ of FA. These results reveal that the simultaneous incorporation of RC and FA can help achieve higher levels of cement replacement;

7. In light of the results obtained in this work, and from a mechanical point of view, the optimal percentage of simultaneous replacement of cement is $10 \%$ of RC and $20 \%$ of FA.

Author Contributions: Conceptualization M.B. and B.C.; performed the experiments, analysed the data, and wrote the paper; M.B. and B.C.; supervised the research work and revised the paper, I.F.S.d.B., C.M. and J.d.B. All the authors contributed to experiment design and analysed and discussed the findings. All authors have read and agreed to the published version of the manuscript.

Funding: This research was funded by the Portuguese Foundation for Science and Technology (FCT) through project PTDC/ECI-COM-31138/2017 (DecarbonCrete).

Institutional Review Board Statement: Not applicable.

Informed Consent Statement: Not applicable.

Data Availability Statement: Not applicable.

Acknowledgments: This study benefitted from the Santander Iberoamérica mobility grant 2020/21, awarded in connection with pre-doctoral university professor scholarship 16/02693, under which Blas Cantero conducted research at the Lisbon University-Instituto Superior Técnico's construction laboratory. The support of the Foundation for Science and Technology, Civil Engineering Research and Innovation for Sustainability (CERIS) research centre, and the Instituto Superior Técnico and a Government of Extremadura, under grant GR 18122 awarded to the MATERIA research group is also acknowledged.

Conflicts of Interest: The authors declare no conflict of interest.

\section{References}

1. Scrivener, K.L.; John, V.M.; Gartner, E.M. Eco-Efficient Cements: Potential Economically Viable Solutions for a Low- $\mathrm{CO}_{2}$ Cement-Based Materials Industry. Cem. Concr. Res. 2018, 114, 2-26. [CrossRef]

2. Lv, Y.; Ye, G.; De Schutter, G. Characterization of Cogeneration Generated Napier Grass Ash and Its Potential Use as SCMs. Mater. Struct. 2019, 52, 87. [CrossRef]

3. Nakanishi, E.Y.; Frías, M.; Martínez-Ramírez, S.; Santos, S.F.; Rodrigues, M.S.; Rodríguez, O.; Savastano, H. Characterization and Properties of Elephant Grass Ashes as Supplementary Cementing Material in Pozzolan $/ \mathrm{Ca}(\mathrm{OH})_{2}$ Pastes. Constr. Build. Mater. 2014, 73, 391-398. [CrossRef]

4. Medina, J.M.; Sáez del Bosque, I.F.; Frías, M.; Sánchez de Rojas, M.I.; Medina, C. Design and Properties of Eco-Friendly Binary Mortars Containing Ash from Biomass-Fuelled Power Plants. Cem. Concr. Compos. 2019, 104, 103372. [CrossRef]

5. Mármol, I.; Ballester, P.; Cerro, S.; Monrós, G.; Morales, J.; Sánchez, L. Use of Granite Sludge Wastes for the Production of Coloured Cement-Based Mortars. Cem. Concr. Compos. 2010, 32, 617-622. [CrossRef]

6. Medina, G.; Sáez del Bosque, I.F.; Frías, M.; Sánchez de Rojas, M.I.; Medina, C. Granite Quarry Waste as a Future Eco-Efficient Supplementary Cementitious Material (SCM): Scientific and Technical Considerations. J. Clean. Prod. 2017, 148, 467-476. [CrossRef]

7. Sáez del Bosque, I.F.; Frías, M.; Sánchez de Rojas, M.I.; Medina, C. Activation Temperature-Mediated Mineralogical Transformations in Slate Quarry Sludge: Pozzolanic Properties. Constr. Build. Mater. 2018, 187, 819-829. [CrossRef]

8. Scrivener, K.; Martirena, F.; Bishnoi, S.; Maity, S. Calcined Clay Limestone Cements (LC3). Cem. Concr. Res. 2018, 114, $49-56$. [CrossRef]

9. Ameri, F; Zareei, S.A.; Behforouz, B. Zero-Cement vs. Cementitious Mortars: An Experimental Comparative Study on Engineering and Environmental Properties. J. Build. Eng. 2020, 32, 101620. [CrossRef]

10. Wang, B.; Yan, L.; Fu, Q.; Kasal, B. A Comprehensive Review on Recycled Aggregate and Recycled Aggregate Concrete. Resour. Conserv. Recycl. 2021, 171, 105565. [CrossRef]

11. Kim, Y.-J. Quality Properties of Self-Consolidating Concrete Mixed with Waste Concrete Powder. Constr. Build. Mater. 2017, 135, 177-185. [CrossRef]

12. Xiao, J.; Ma, Z.; Sui, T.; Akbarnezhad, A.; Duan, Z. Mechanical Properties of Concrete Mixed with Recycled Powder Produced from Construction and Demolition Waste. J. Clean. Prod. 2018, 188, 720-731. [CrossRef] 
13. Oliveira, T.C.F.; Dezen, B.G.S.; Possan, E. Use of Concrete Fine Fraction Waste as a Replacement of Portland Cement. J. Clean. Prod. 2020, 273, 123126. [CrossRef]

14. Moreno-Juez, J.; Vegas, I.J.; Frías Rojas, M.; Vigil de la Villa, R.; Guede-Vázquez, E. Laboratory-Scale Study and Semi-Industrial Validation of Viability of Inorganic CDW Fine Fractions as SCMs in Blended Cements. Constr. Build. Mater. 2021, $271,121823$. [CrossRef]

15. Kim, Y.J.; Choi, Y.W. Utilization of Waste Concrete Powder as a Substitution Material for Cement. Constr. Build. Mater. 2012, 30, 500-504. [CrossRef]

16. Garcia-Lodeiro, I.; Carcelen-Taboada, V.; Fernández-Jiménez, A.; Palomo, A. Manufacture of Hybrid Cements with Fly Ash and Bottom Ash from a Municipal Solid Waste Incinerator. Constr. Build. Mater. 2016, 105, 218-226. [CrossRef]

17. Sánchez Berriel, S.; Favier, A.; Rosa Domínguez, E.; Sánchez Machado, I.R.; Heierli, U.; Scrivener, K.; Martirena Hernández, F.; Habert, G. Assessing the Environmental and Economic Potential of Limestone Calcined Clay Cement in Cuba. J. Clean. Prod. 2016, 124, 361-369. [CrossRef]

18. Ibáñez-Gosálvez, J.; Real-Herraiz, T.; Ortega, J.M. Performance of Mortars Made Using Ternary Binders with Addition of Slag, Fly Ash and Limestone Exposed to a Real Environmental Condition Compatible with Exposure Class XC3. Materials 2021, 14, 5937. [CrossRef]

19. Chen, X.; Li, Y.; Bai, H.; Ma, L. Utilization of Recycled Concrete Powder in Cement Composite: Strength, Microstructure and Hydration Characteristics. J. Renew. Mater. 2021, 9, 2189. [CrossRef]

20. EN 1097; Tests for Mechanical and Physical Properties of Aggregates. Part 6: Determination of Particle Density and Water Absorption. European Committee for Standardization: Brussels, Belgium, 2014.

21. Faury, J. Le Béton; Dunod: París, France, 1958.

22. EN 206 Concrete; Part 1: Specification, Performance, Production and Conformity. European Committee for Standardization: Brussels, Belgium, 2013.

23. UNE 80103; Test Methods of Cements. Physical Analysis. Actual Density Determination. Spanish Committee for Standardization: Madrid, Spain, 2013.

24. EN 1015-3; Methods of Test for Mortar for Masonry-Part 3: Determination of Consistence of Fresh Mortar. European Committee for Standardization: Brussels, Belgium, 1999.

25. EN 1015-6; Methods of Test for Mortar for Masonry—Part 6: Determination of Bulk Density of Fresh Mortar. European Committee for Standardization: Brussels, Belgium, 1999.

26. EN 12350; Testing Fresh Concrete. Part 7: Air Content-Pressure Methods. European Committee for Standardization: Brussels, Belgium, 2009.

27. EN 1015-11; Methods of Test for Mortar for Masonry-Part 11: Determination of Flexural and Compressive Strength of Hardened Mortar. European Committee for Standardization: Brussels, Belgium, 2020.

28. ASTM E1876-15; Standard Test Method for Dynamic Young's Modulus, Shear Modulus, and Poisson's Ratio by Impulse Excitation of Vibration. ASTM International: West Conshohocken, PA, USA, 2016.

29. EN 12504-4; Part 4: Determination of Ultrasonic Pulse Velocity. European Committee for Standardization: Brussels, Belgium, 2004.

30. Hamidi, M.; Kacimi, L.; Cyr, M.; Clastres, P. Evaluation and Improvement of Pozzolanic Activity of Andesite for Its Use in Eco-Efficient Cement. Constr. Build. Mater. 2013, 47, 1268-1277. [CrossRef]

31. Cantero, B.; Bravo, M.; de Brito, J.; Sáez del Bosque, I.F.; Medina, C. Mechanical Behaviour of Structural Concrete with Ground Recycled Concrete Cement and Mixed Recycled Aggregate. J. Clean. Prod. 2020, 275, 122913. [CrossRef]

32. Duan, Z.; Hou, S.; Xiao, J.; Singh, A. Rheological Properties of Mortar Containing Recycled Powders from Construction and Demolition Wastes. Constr. Build. Mater. 2020, 237, 117622. [CrossRef]

33. Wu, H.; Liang, C.; Xiao, J.; Xu, J.; Ma, Z. Early-age Behavior and Mechanical Properties of Cement-based Materials with Various Types and Fineness of Recycled Powder. Struct. Concr. 2021, 1-20. [CrossRef]

34. Torres-Gómez, A.I.; Ledesma, E.F.; Otero, R.; Fernández, J.M.; Jiménez, J.R.; De Brito, J. Combined Effects of Non-Conforming Fly Ash and Recycled Masonry Aggregates on Mortar Properties. Materials 2016, 9, 729. [CrossRef]

35. Kurda, R.; de Brito, J.; Silvestre, J.D. Combined Influence of Recycled Concrete Aggregates and High Contents of Fly Ash on Concrete Properties. Constr. Build. Mater. 2017, 157, 554-572. [CrossRef]

36. Gonçalves, T.; Silva, R.V.; de Brito, J.; Fernández, J.M.; Esquinas, A.R. Mechanical and Durability Performance of Mortars with Fine Recycled Concrete Aggregates and Reactive Magnesium Oxide as Partial Cement Replacement. Cem. Concr. Compos. 2020, 105, 103420. [CrossRef]

37. Vance, K.; Kumar, A.; Sant, G.; Neithalath, N. The Rheological Properties of Ternary Binders Containing Portland Cement, Limestone, and Metakaolin or Fly Ash. Cem. Concr. Res. 2013, 52, 196-207. [CrossRef]

38. Demirboğa, R. Influence of Mineral Admixtures on Thermal Conductivity and Compressive Strength of Mortar. Energy Build. 2003, 35, 189-192. [CrossRef]

39. Dhandapani, Y.; Santhanam, M.; Kaladharan, G.; Ramanathan, S. Towards Ternary Binders Involving Limestone Additions-A Review. Cem. Concr. Res. 2021, 143, 106396. [CrossRef]

40. Jiang, H.; Yi, H.; Yilmaz, E.; Liu, S.; Qiu, J. Ultrasonic Evaluation of Strength Properties of Cemented Paste Backfill: Effects of Mineral Admixture and Curing Temperature. Ultrasonics 2020, 100, 105983. [CrossRef] 
41. ASTM C618-19; Standard Specification for Coal Fly Ash and Raw or Calcined Natural Pozzolan for Use in Concrete. ASTM: West Conshohocken, PA, USA, 2014.

42. Horsakulthai, V. Effect of Recycled Concrete Powder on Strength, Electrical Resistivity, and Water Absorption of Self-Compacting Mortars. Case Stud. Constr. Mater. 2021, 15, e00725. [CrossRef]

43. Jiang, D.; Li, X.; Lv, Y.; Zhou, M.; He, C.; Jiang, W.; Liu, Z.; Li, C. Utilization of Limestone Powder and Fly Ash in Blended Cement: Rheology, Strength and Hydration Characteristics. Constr. Build. Mater. 2020, 232, 117228. [CrossRef]

44. Dehghan, S.M.; Najafgholipour, M.A.; Baneshi, V.; Rowshanzamir, M. Experimental Study on Effect of Water-Cement Ratio and Sand Grading on Workability and Mechanical Properties of Masonry Mortars in Iran. Iran. J. Sci. Technol. Trans. Civ. Eng. 2019, 43, 21-32. [CrossRef]

45. Cantero, B.; Sáez del Bosque, I.F.; Matías, A.; Sánchez de Rojas, M.I.; Medina, C. Water Transport Mechanisms in Concretes Bearing Mixed Recycled Aggregates. Cem. Concr. Compos. 2020, 107, 103486. [CrossRef]

46. Paris, J.M.; Roessler, J.G.; Ferraro, C.C.; De Ford, H.D.; Townsend, T.G. A Review of Waste Products Utilized as Supplements to Portland Cement in Concrete. J. Clean. Prod. 2016, 121, 1-18. [CrossRef]

47. Bogas, J.A.; Gomes, M.G.; Gomes, A. Compressive Strength Evaluation of Structural Lightweight Concrete by Non-Destructive Ultrasonic Pulse Velocity Method. Ultrasonics 2013, 53, 962-972. [CrossRef]

48. Hong, G.; Oh, S.; Choi, S.; Chin, W.-J.; Kim, Y.-J.; Song, C. Correlation between the Compressive Strength and Ultrasonic Pulse Velocity of Cement Mortars Blended with Silica Fume: An Analysis of Microstructure and Hydration Kinetics. Materials 2021, 14, 2476. [CrossRef] [PubMed]

49. Han, Y.; Lin, R.; Wang, X.-Y. Performance and Sustainability of Quaternary Composite Paste Comprising Limestone, Calcined Hwangtoh Clay, and Granulated Blast Furnace Slag. J. Build. Eng. 2021, 43, 102655. [CrossRef]

50. Ibáñez-Gosálvez, J.; Real-Herraiz, T.; Ortega, J.M. Microstructure, Durability and Mechanical Properties of Mortars Prepared Using Ternary Binders with Addition of Slag, Fly Ash and Limestone. Appl. Sci. 2021, 11, 6388. [CrossRef]

51. Alnahhal, M.F.; Alengaram, U.J.; Jumaat, M.Z.; Alqedra, M.A.; Mo, K.H.; Sumesh, M. Evaluation of Industrial By-Products as Sustainable Pozzolanic Materials in Recycled Aggregate Concrete. Sustainability 2017, 9, 767. [CrossRef]

52. Costa, C.; Marques, J.C. Feasibility of Eco-Friendly Binary and Ternary Blended Binders Made of Fly-Ash and Oil-Refinery Spent Catalyst in Ready-Mixed Concrete Production. Sustainability 2018, 10, 3136. [CrossRef]

53. Saint-Pierre, F.; Philibert, A.; Giroux, B.; Rivard, P. Concrete Quality Designation Based on Ultrasonic Pulse Velocity. Constr. Build. Mater. 2016, 125, 1022-1027. [CrossRef]

54. Çelikten, S. Mechanical and Microstructural Properties of Waste Andesite Dust-Based Geopolymer Mortars. Adv. Powder Technol. 2021, 32, 1-9. [CrossRef]

55. Demirboğa, R.; Türkmen, İ.; Karakoç, M.B. Relationship between Ultrasonic Velocity and Compressive Strength for High-Volume Mineral-Admixtured Concrete. Cem. Concr. Res. 2004, 34, 2329-2336. [CrossRef]

56. Trtnik, G.; Kavčič, F.; Turk, G. Prediction of Concrete Strength Using Ultrasonic Pulse Velocity and Artificial Neural Networks. Ultrasonics 2009, 49, 53-60. [CrossRef]

57. Arribas, I.; Vegas, I.; García, V.; Vigil de la Villa, R.; Martínez-Ramírez, S.; Frías, M. The Deterioration and Environmental Impact of Binary Cements Containing Thermally Activated Coal Mining Waste Due to Calcium Leaching. J. Clean. Prod. 2018, 183, 887-897. [CrossRef]

58. Hossain, U.; Poon, C.S.; Lo, I.M.C.; Cheng, J.C.P. Comparative Environmental Evaluation of Aggregate Production from Recycled Waste Materials and Virgin Sources by LCA. Resour. Conserv. Recycl. 2016, 109, 67-77. [CrossRef]

59. García-Segura, T.; Yepes, V.; Alcalá, J. Life Cycle Greenhouse Gas Emissions of Blended Cement Concrete Including Carbonation and Durability. Int. J. Life Cycle Assess. 2014, 19, 3-12. [CrossRef] 